\title{
Chemical control of rice whitefly (Aleurocybotus occiduus Maria) in Chitwan, Nepal
}

\author{
S Pokhrel ${ }^{*}$ and SP Pokhrel ${ }^{* *}$
}

\begin{abstract}
Effectiveness of five common insecticides was evaluated against a newly established rice insect, Whitefly (Aleurocybotus occiduus Maria) on main season rice (var: Sabitri) at Bharatpur-10, Chitwan $(350 \mathrm{~m})$ in 2005. The insecticides tested were: Noorani (Chloropyrifos 50\% + Cypermethrin 5\% EC) @2ml/litre of water, Rogar@1.5ml/litre of water, Phoskil (monocrotophos)@2ml/litre of water, Furadan@1kg a.i/ha and Anumida (Imidacloprid 17.8\% SL)@1 $1 \mathrm{ml} / 4$ litre of water. The plant growth parameters: plant height, number of yellow and green leaves, active and dead tillers and the grain yield were recorded. Anumida (Imidacloprid 17.8\% SL) provided perfect control of Whitefly and gave the highest plant height ( $60 \mathrm{vs} 50 \mathrm{~cm}$ ), highest leaf number (46.7 vs 3.7), highest tillering (4.4 folds), highest green infertile tillers (16.3 vs6.7) with highest number of ears (3.0 vs 0.0 ) and grain number (26.3 vs 0.0)/hill. Anumida (Imidacloprid $17.8 \% \mathrm{SL}$ ) also provided comparatively lower leaf yellowing and drying ( 8.5 vs 22.5 ) then the control. Anumida (Imidacloprid 17.8\% SL) @ 1ml/ 4 liter of water is recommended against rice Whitefly however, Rogar@1.5 ml/litre of water, Phoskil (monocrotophos)@2ml/litre of water, Noorani (Chloropyrifos 50\% + Cypermethrine 5\% EC) @ 2m1/liter of water and Furadan @ $1 \mathrm{~kg}$ a.i./ha also can serve the purpose. The hills not using insecticide were completely failure to produce ears and grains.
\end{abstract}

Key words: Whitefly, insecticide, newly established, perfect control

\section{Introduction}

Rice is the main food In Nepal which is grown through out the tarai region followed by mid hills and also in high hills like Jumla valley (CBS, 1999). The total area under rice is estimated 1506340 ha with the estimated annual yield $3640860 \mathrm{mt}$ in Nepal (CBS, 1999). However, the national production is not far to meet the per capita requirement of rice, ie. $126.02 \mathrm{~kg}$ (Bista, 2002).

Chitwan is one of the important rice-growing districts in Nepal. The total rice growing area in this district is 30198 ha with the annual production of $90594 \mathrm{mt}$ rice grain (DADO, 1996). Few VDCs of eastern Chitwon and some more patches of western Chitwan are having year

\footnotetext{
* Crop Development Directorate, Lalitpur, Nepal, surojpokhrel@yahoo.com

** District Agriculture Development Office, Chitwan, Nepal
} 
round irrigation, where rice is grown twice a year. Sabitri, BG, Mansuli, Anadi, Masino, Radha-4 are the major rice varieties grown in the main rice growing season (Pokhrel, 2002). The district is supplying rice to its neighboring hill districts including the capital city Kathmandu.

Repeated outbreaks of rice pest in Chitwan valley are threatening the rice production year after year. Severe outbreaks of plant hoppers (BPH and WBPH) on early rice (Feb/MarchJune/July) in eastern Chitwan in 1996 (2053 BS) damaged 1568 ha rice crop resulting 4262 mt yield loss equivalent to Rs. 29834210 (DADO, 1996; Himalayan Times Sep 30, 1996; Gorkhapatra Daily, 11 Sept, 1996; Pokhrel, 1998; Pokhrel et. al, 1998-99). Whitefly was formerly not reported as an insect pest of rice in the world however, a severe outbreak of which occurred on the main season rice during August-September 2003 (Bhadra-Ashwin 2060 BS) in Chitwan valley. The outbreak was extended in a vast area of Chitwan, Nawalparasi and in smaller pockets of other hilly districts: Tanahun, Lamjung, Gorkha and Kaski during the same period. A maximum of 1000 Whitefly nymphs per tiller were observed from the rice field from Chitwan. Numerous adults (uncountable in number) were observed on tapping the rice hills. Green areas of the leaves were totally become reddishyellow. The extentionists form DADO offices and the pathologist from NRRP Hardinath got confused with bacterial blight, phyto-toxicity and nutritional deficiencies. However, an extensive field survey carried during early September found that the problem was really by an insect Whitefly, Aleurocybotus occiduus Maria. It affected a total of 20561 ha rice field, losing $9448 \mathrm{mt}$ rice yield. Higher the population of Whitefly proportionally decreased the tillers number/hill, fertile tillers/hill, grain weight/panicle and the grain yield/ha. Rice plants infested with high population of Whitefly (898/tiller) failed to gave rice yield, where medium population (335/ tiller) gave $1287 \mathrm{~kg}$ rice yield/ha and low population (103/tiller) gave $3456.0 \mathrm{~kg}$ rice yield. Kanchhi Mansuli (4200 kg/ha) and Mansuli (3960 kgs/ha) were comparative tolerant varieties than the Sabitri. Parasitoid, Encarsia sp was fond most functional natural enemy against Whitefly in the field. However, the population build up of the parasitoid was observed quite late. Whiteflies were fully controlled after heading of rice after which the rice plants were recovered in some extent (Pokhrel, 2003).

Another outbreak of rice Whitefly appeared in 2005. It was extensively extended through out the Chitwan valley including Nawalpur area of Nawalparasi district. Whole rice field was converted into reddish-yellow (Figure 1). A total of 1256 nymphs/tiller was counted in Ratnanagar municipality-3 (Figure 2). 


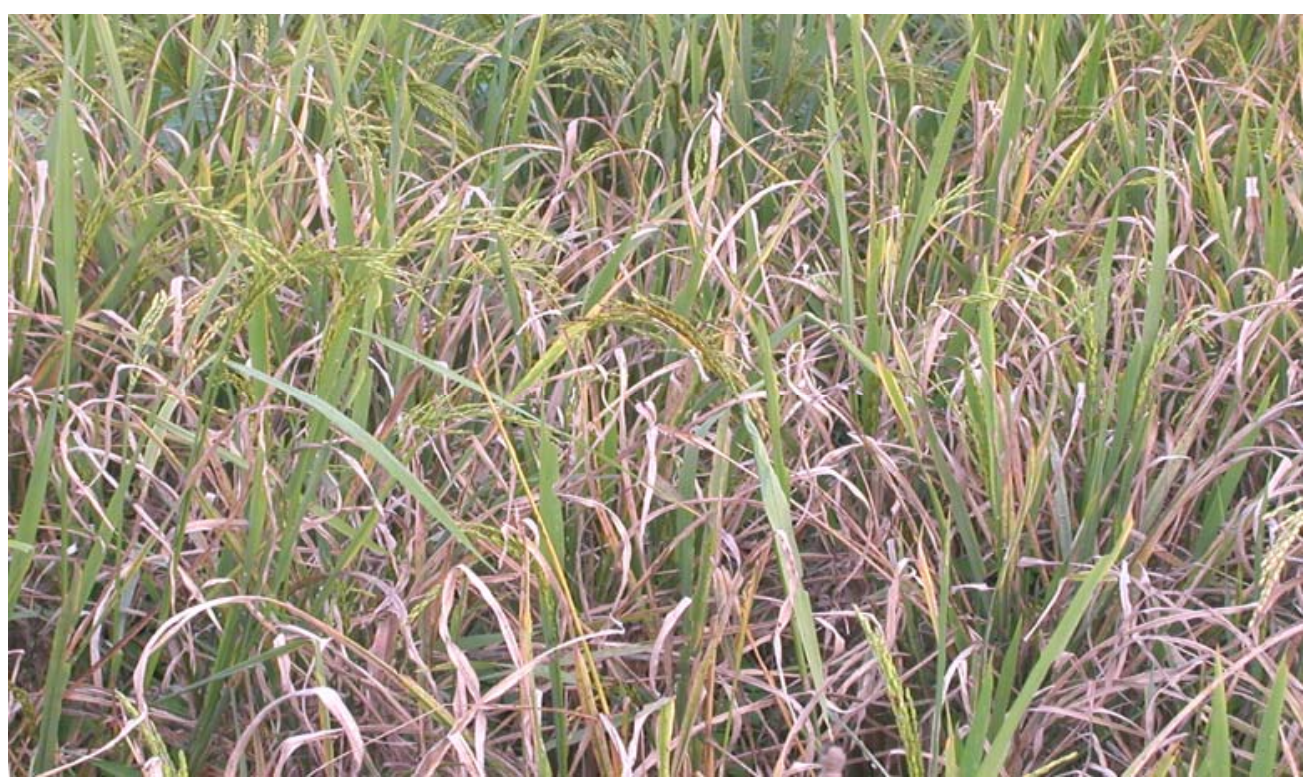

Figure 1. An overview of severely infested rice field, Chitwan

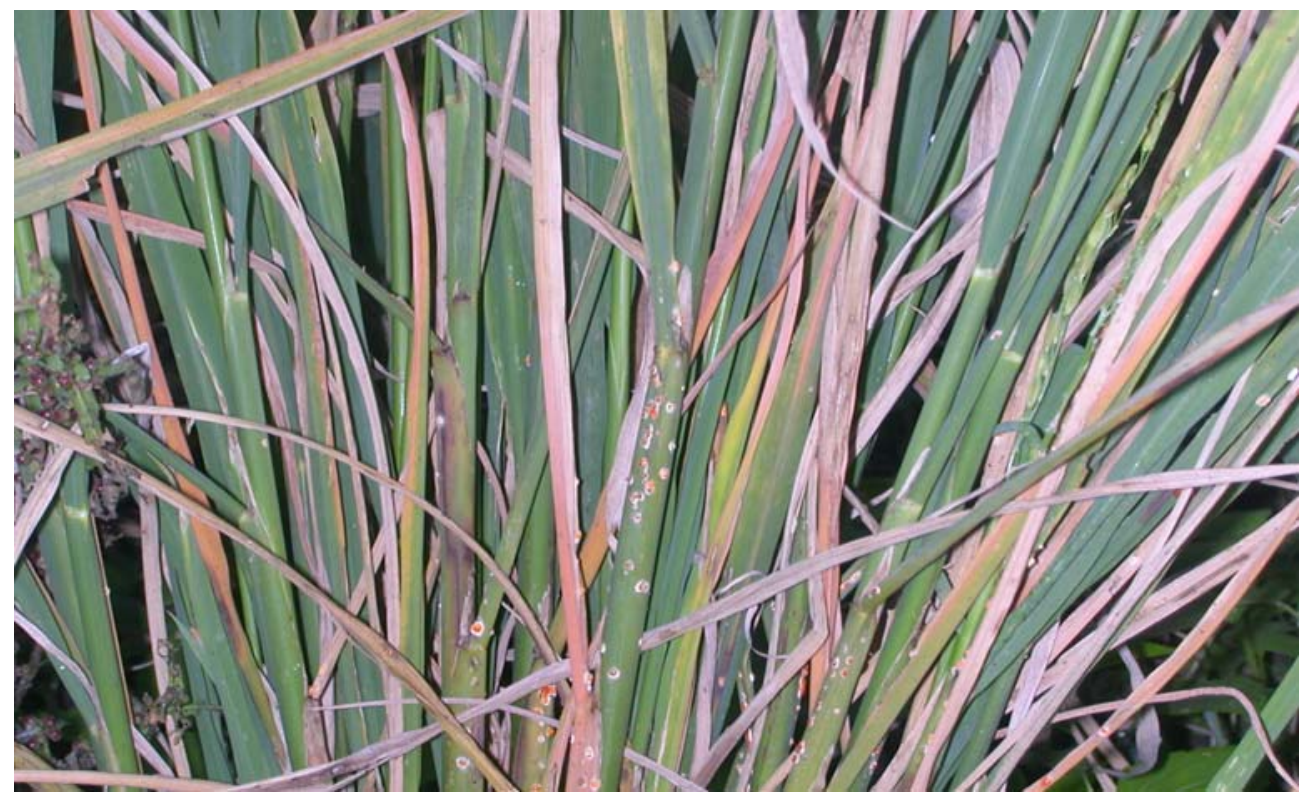

Figure 2. Whitefly nymphs on rice tillers, Chitwan

Farmers asked for the immediate control measure with us but there was no instant answer. Cultural control, bio control and selection of resistant varieties could be the possible solution which could not satisfy the farmer's immediately. So, evaluation of the possible chemical agent available in the local market was necessary. 
Cereals were the only major food crops that had remained free from whitefly species until 2003 in Central America. A new Whitefly species, identified as Aleurocybotus occidum Marin caused total crop losses in rice and sorghum field in N. W. El. Salvador in 2003. The pest was observed colonized on rice, maize, sorghum and forage pasture in Meso America and the Amazan region of Peru (TWFP, 2005).

Whitefly is the poly-phagus, tiny insects of $1-1.5 \mathrm{~mm}$ in size. Adults are having two pairs of white wings with prominently longer hind wings. These migratory adult lay up to 120 eggs, which are sub-elliptical in shape, light yellow in color and are laid singly on the under surface of the leaves and succulent stems. Nymph hatch in 3-7 days and go through 4 instars, which are stationary. Pupation is also stationary which ends in 2-8 days. The stationary nymphs are the most harmful stage, which sucks the plant sap from stems and leaves. The total life cycle from egg to adult is 14-120 days (PCIP, 2004).

Nutrimac (2004) recommended bio control of Whitefly with Encarsia formosa@ 300010000 n/a or Eretmocerus eremicus@ 8000 n/a. However, PAU (2004) recommended synthetic pyrethroids e.g. Triazophous and Acmsabati (2004) recommended Apploud against it.

\section{Materials and methods}

Plastic pots of $25 \mathrm{~cm}$ diameter and $25 \mathrm{~cm}$ height were filled with puddle, 1:5 FYM and soil. Two hills of one month older, already transplanted rice (Sabitri) having about equal number of tillers, green leaf number, height and Whitefly nymphs were uprooted and replanted in each pot and irrigated alternate a day (Figure 3). Each sets of hills was sprayed with an insecticide, twice in 15 days intervals except Furadan which applied only once. Each pot was covered with 40x40x100 cm, fine meshed, white, nylon net hanged with rope and tied with the bamboo polls. Each pot was considered as an experiment unit laid on RCBD replicated thrice. Following were the treatments:

1. Noorani (Chloropyrifos 50\% + Cypermethrine 5\% EC) @ 2ml/litre of water

2.Rogar@1.5 ml / litre of water

3. Phoskil (Monocrotophos) @ 2ml / litre of water

4. Furadan@1 kg a.i / ha

5. Anumida (Imidacloprid 17.8\% SL)@1ml / 4 litre of water

6. Control

The experiment side was at District Agriculture Development Office, Bharatpur-10, Chitwan, $350 \mathrm{~m}$. The differences on plant growth parameters: plant height, number of yellow and green leaves, were recorded before and one month after the application of the first treatment. Number of dead and active tillers and grains per hill was counted at the maturity. 


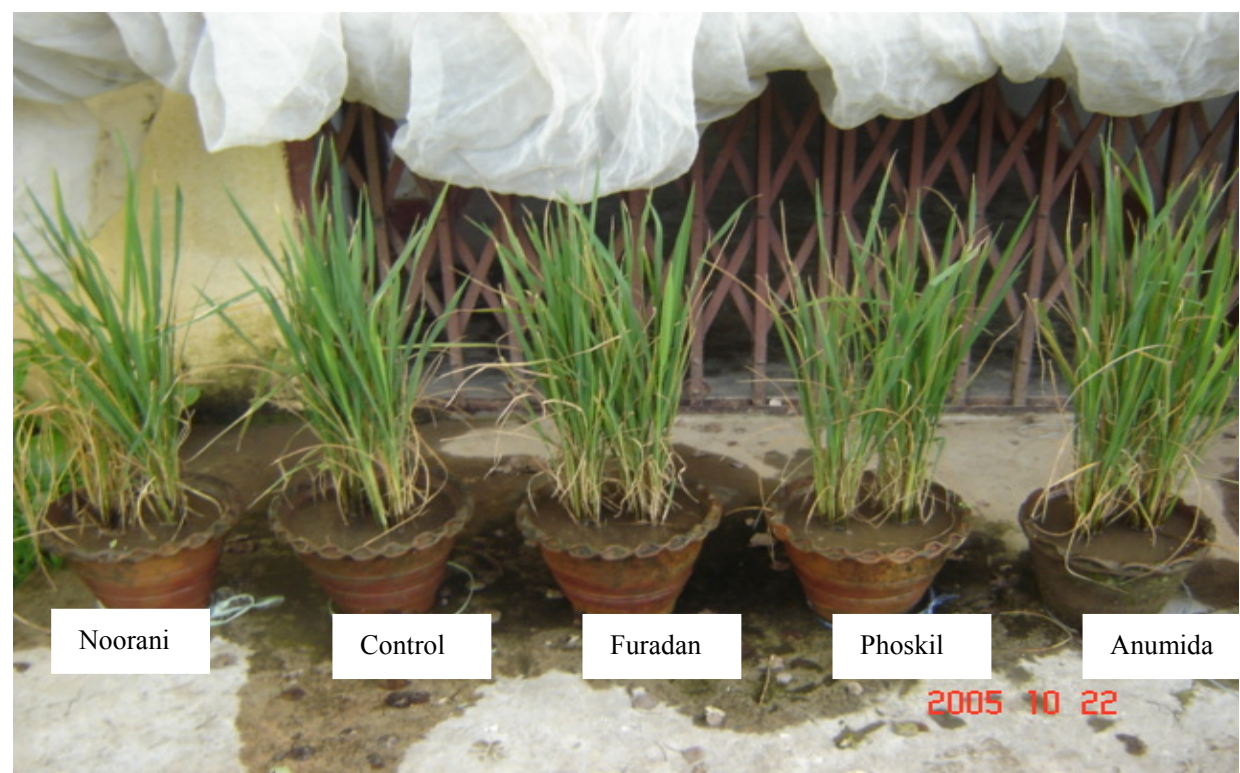

Figure 3. Overview of a replication of experiment, Chitwan, 2005

\section{Results and discussions}

\section{Plant height}

Plant height increased with in a month of replanting was found significantly higher by $100 \%$ on the pot sprayed with Anumida (Imidacloprid 17.8\% SL) @ 1ml / 4 litre of water $(30 \mathrm{~cm}$ ) and Noorani@2ml / litre of water $(30 \mathrm{~cm})$. However it was only 66.7\% $\%(20 \mathrm{~cm})$ in case of control (Figure 4, Table 1). The plant height in all the treatments was higher than the control. It seems that the chemical control help for decreasing the whitefly population which, subsequently help on increasing the plant height.

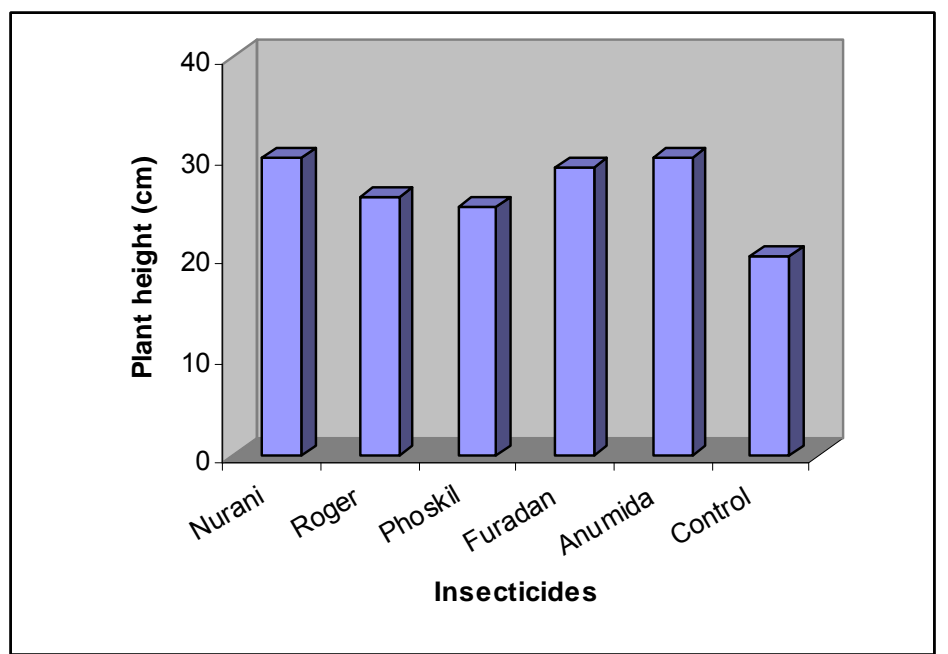

Figure 4. Plant height increased one month after insecticide use, Chitwan, 2005 
Table 1. Increased plant height after one month of treatment, Chitwan, 2005

\begin{tabular}{llcccc}
\hline \multirow{2}{*}{ SN } & \multirow{2}{*}{ Treatment } & \multicolumn{4}{c}{ Increase in plant height (cm) } \\
\cline { 3 - 6 } & & $\mathbf{R 1}$ & $\mathbf{R 2}$ & $\mathbf{R 3}$ & T mean \\
\hline 1 & Noorani & 29.0 & 32.0 & 29.0 & 30.0 \\
2 & Roger & 26.0 & 25.0 & 27.0 & 26.0 \\
3 & Phoskil & 25.0 & 24.0 & 27.0 & 25.0 \\
4 & Furadan & 28.0 & 28.0 & 31.0 & 29.0 \\
5 & Anumida & 32.0 & 30.0 & 28.0 & 30.0 \\
6 & Control & 19.0 & 20.0 & 21.0 & 20.0 \\
& R mean & $\mathbf{2 6 . 5}$ & $\mathbf{2 6 . 5}$ & $\mathbf{2 7 . 2}$ & $\mathbf{2 6 . 7}$ \\
\hline
\end{tabular}

Mean plant height at re-transplanting was $30 \mathrm{~cm}$

\section{Leaf number}

The number of leaf developed after one month of treatment application was found significantly higher on Anumida (Imidacloprid 17.8\% SL) @ 1 $1 \mathrm{ml} / 4$ litre of water ( $\mathrm{N}=46.7)$ followed by Phoskil ( $\mathrm{N}=41.0)$ (Figure 5, Table 2). However, all the chemicals were able to reducing the Whitefly population. They were able to help on producing more number of leaves per hill then control. The hills on a control plot were able to produce very few leaf number $(\mathrm{N}=3.7)$.

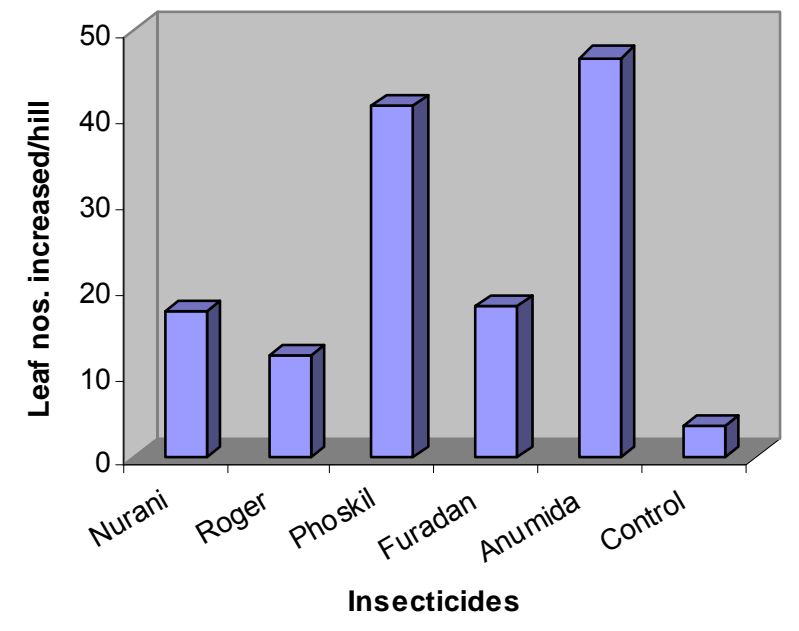

Figure 5. Number of leaves increased one month after insecticide use, Chitwan, 2005 
Table 2. Increased leaf number after a month of pesticide use, Chitwan, 2005

\begin{tabular}{clcccc}
\hline \multirow{2}{*}{ SN } & \multirow{2}{*}{ Treatment } & \multicolumn{4}{c}{ Increase in green leaf number (Nos/hill) } \\
\cline { 3 - 6 } & & R1 & R2 & R3 & T mean \\
\hline 1 & Noorani & 19.0 & 16.0 & 16.0 & 17.0 \\
2 & Roger & 11.0 & 11.0 & 14.0 & 12.0 \\
3 & Phoskil & 42.0 & 42.0 & 39.0 & 41.0 \\
4 & Furadan & 17.0 & 19.0 & 17.0 & 17.7 \\
5 & Anumida & 47.0 & 48.0 & 45.0 & 46.7 \\
6 & Control & 4.0 & 4.0 & 3.0 & 3.7 \\
& R mean & $\mathbf{2 3 . 3}$ & $\mathbf{2 3 . 3}$ & $\mathbf{2 2 . 3}$ & $\mathbf{2 3 . 0}$ \\
\hline
\end{tabular}

Mean green leaves/hill at the time of re transplanting was $15 /$ hill

\section{Leaf yellowing and drying}

All the hills selected at the time of replanting were having about 10 yellow and dry leaves. However, the rate of leaf yellowing/drying was dramatically decreased on the pots treated with insecticides. But yellowing/drying was continue with control pots. The highest yellow/dry leaf number $(\mathrm{N}=22.5)$ was encountered with control hills after one month of replanting (Figure 6, Table 3). However, the rate of leaf drying/yellowing was lowest in Rogar treated plot by $88.6 \%(\mathrm{~N}=3.0)$, by $66.7 \%$ in Furadan, $62.2 \%$ in Anumida (Imidacloprid $17.8 \% \mathrm{SL}$ ), $60.0 \%$ in Noorani and $57.8 \%$ in Phoskil treated pots compared to control.

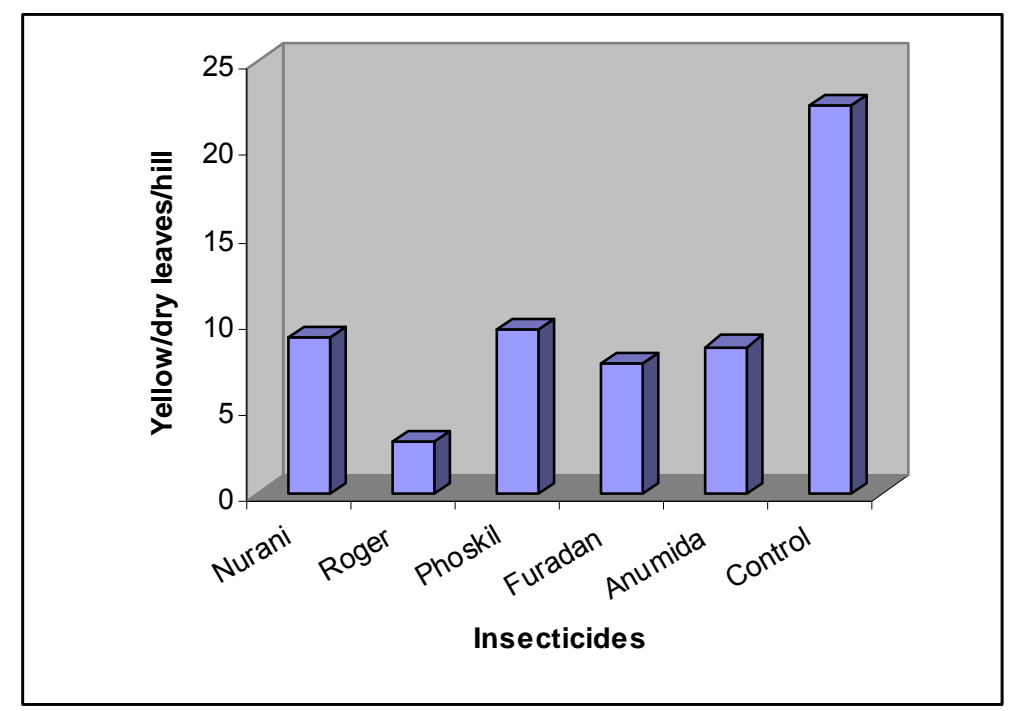

Figure 6. Increase in yellow/dry leaves one month after insecticide use, Chitwan, 2005 
Table 3. Leaf yellowing/drying after a month of insecticide use, Chitwan, 2005

\begin{tabular}{llcccc}
\hline \multirow{2}{*}{ SN } & \multirow{2}{*}{ Treatment } & \multicolumn{4}{c}{ Increase in yellow/dry leaves (Nos/hill) } \\
\cline { 3 - 6 } & & $\mathbf{R 1}$ & $\mathbf{R 2}$ & $\mathbf{R 3}$ & T mean \\
\hline 1 & Noorani & 9.0 & 8.0 & 10.0 & 9.0 \\
2 & Roger & 3.0 & 3.0 & 3.0 & 3.0 \\
3 & Phoskil & 8.5 & 10.0 & 10.0 & 9.5 \\
4 & Furadan & 8.0 & 7.0 & 7.5 & 7.5 \\
5 & Anumida & 8.5 & 8.0 & 9.0 & 8.5 \\
6 & Control & 21.0 & 23.0 & 23.5 & 22.5 \\
& R mean & $\mathbf{9 . 7}$ & $\mathbf{9 . 8}$ & $\mathbf{1 0 . 5}$ & $\mathbf{1 0 . 0}$ \\
\hline
\end{tabular}

Mean number of leaf yellowing/drying at the time of re transporting was 10/hill

\section{Tiller number}

The mean tiller number of the selected hills at the time of re-planting was about 8 . It was significantly increased in all the pots treated with different insecticides. The tillering rate was 4.4 folds higher in Anumida (Imidacloprid 17.8\% SL) treated pots $(\mathrm{N}=16.3)$ then the control \{Figure 7, Figure 8, Table 4). However, it was almost double in rest of the treatments compared to control. Majority tillers were failure to produce ear because, the hills before re-transplanting in the fields were heavily infected with Whitefly thus the plant vigor was seriously hampered. The number of dead tillers per hill was lowest with the Furadan treated hills $(\mathrm{N}=2.7)$ followed by Rogar $(\mathrm{N}=3.7)$ and phoskil $(\mathrm{N}=4.0)$ treated hills respectively (Figure 9, Table 5). Another major portion of the tillers were alive however, they fail to heading (Figure 10, Table 6).
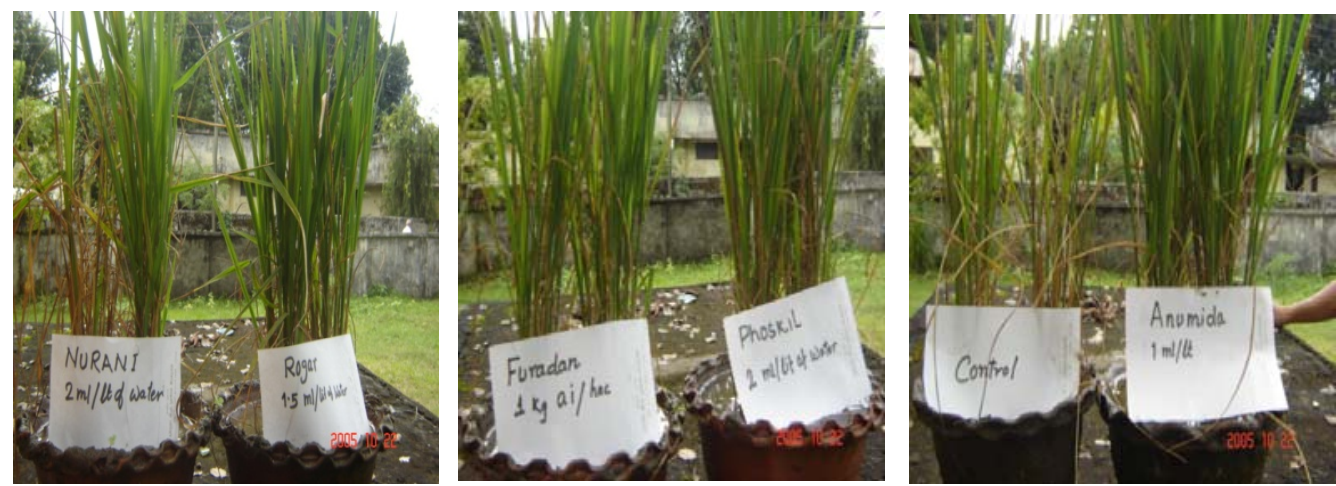

Figure 7. Difference on tiller number a month after insecticide used, Chitwan 


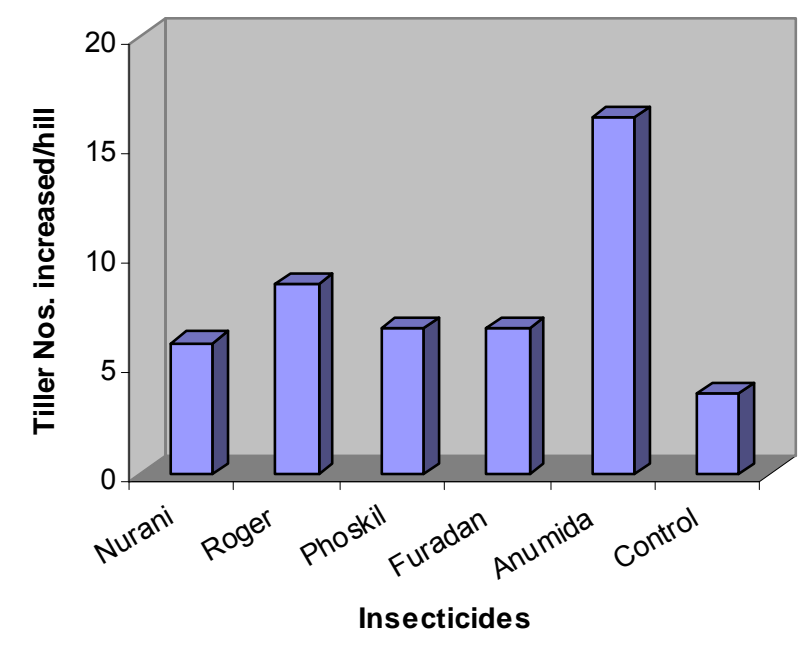

Figure 8. Tiller number increased one month after insecticide use, Chitwan

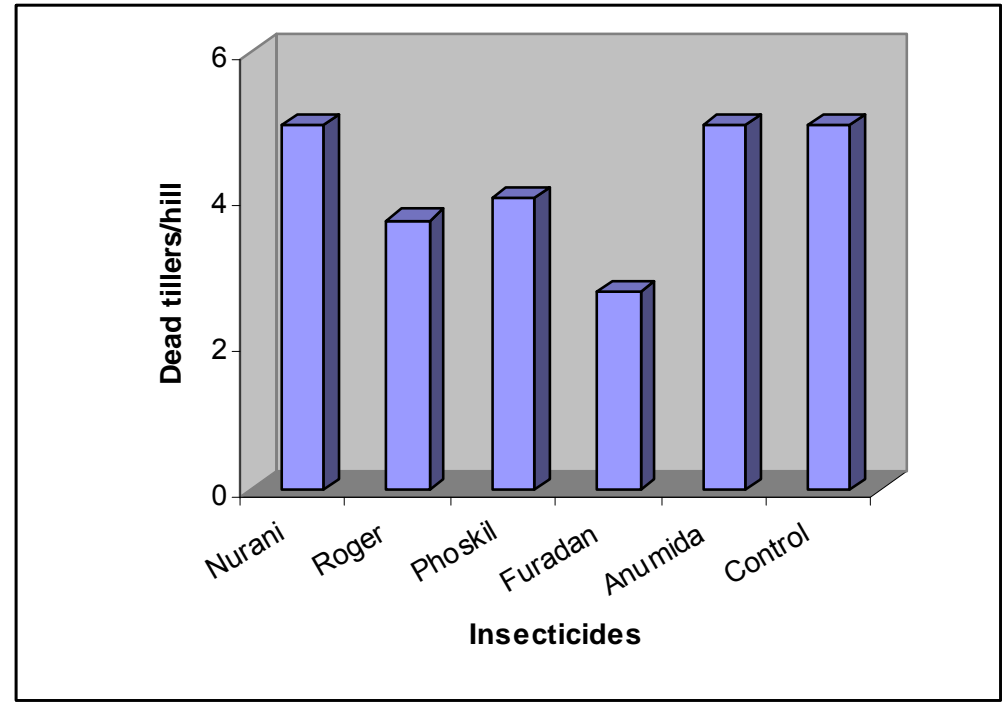

Figure 9. Dead tillers/hill after one month of insecticide use, Chitwan 
Table 4. Increased tiller number after one month of re transplanting, Chitwan

\begin{tabular}{llcccc}
\hline \multirow{2}{*}{ SN } & \multirow{2}{*}{ Treatment } & \multicolumn{4}{c}{ Increase in tiller number (Nos/ hill) } \\
\cline { 3 - 6 } & & $\mathbf{R 1}$ & $\mathbf{R 2}$ & $\mathbf{R 3}$ & T mean \\
\hline 1 & Noorani & 8.0 & 5.0 & 5.0 & 6.0 \\
2 & Roger & 9.0 & 8.0 & 9.0 & 8.7 \\
3 & Phoskil & 7.0 & 6.0 & 7.0 & 6.7 \\
4 & Furadan & 7.0 & 6.0 & 7.0 & 6.7 \\
5 & Anumida & 15.0 & 17.0 & 17.0 & 16.3 \\
6 & Control & 5.0 & 4.0 & 2.0 & 3.7 \\
& R mean & $\mathbf{8 . 5}$ & $\mathbf{7 . 7}$ & $\mathbf{7 . 8}$ & $\mathbf{8 . 0}$ \\
\hline
\end{tabular}

Mean tillers/hill was 8 at the time of re transplanting

The hills having the higher number of total tillers were also having more number of such sterile tillers. Anumida (Imidacloprid 17.8\% SL) treated hills were having the highest sterile tiller /hill ( $\mathrm{N}=16.3)$ followed by Rogar $(\mathrm{N}=10.7)$ and Furadan $(\mathrm{N}=10.3)$ (Figure 10, Table 6).

Table 5. Difference on the number of dead tillers at the time of maturity, Chitwan

\begin{tabular}{lllccc}
\hline \multirow{2}{*}{ SN } & \multirow{2}{*}{ Treatment } & \multicolumn{4}{c}{ Dead tillers (Nos/hill) } \\
\cline { 3 - 6 } & & R1 & R2 & R3 & T mean \\
\hline 1 & Noorani & 6.0 & 3.0 & 3.0 & 5.0 \\
2 & Roger & 4.0 & 3.0 & 4.0 & 3.7 \\
3 & Phoskil & 4.0 & 4.0 & 4.0 & 4.0 \\
4 & Furadan & 3.0 & 3.0 & 2.0 & 2.7 \\
5 & Anumida & 6.0 & 4.0 & 5.0 & 5.0 \\
6 & Control & 5.0 & 5.0 & 5.0 & 5.0 \\
& R mean & $\mathbf{4 . 7}$ & $\mathbf{3 . 7}$ & $\mathbf{3 . 8}$ & $\mathbf{4 . 2}$ \\
\hline
\end{tabular}

Table 6. Live tillers not producing ears at the time of maturity, Chitwan

\begin{tabular}{llcccc}
\hline \multirow{2}{*}{ SN } & \multirow{2}{*}{ Treatment } & \multicolumn{4}{c}{ Infertile live tillers/hill } \\
\cline { 3 - 6 } & & R1 & R2 & R3 & T mean \\
\hline 1 & Noorani & 9.0 & 8.0 & 5.0 & 7.3 \\
2 & Roger & 11.0 & 10.0 & 11.0 & 10.7 \\
3 & Phoskil & 9.0 & 8.0 & 9.0 & 8.7 \\
4 & Furadan & 10.0 & 10.0 & 11.0 & 10.3 \\
5 & Anumida & 14.0 & 18.0 & 17.0 & 16.3 \\
6 & Control & 8.0 & 7.0 & 5.0 & 6.7 \\
& R mean & $\mathbf{1 0 . 2}$ & $\mathbf{1 0 . 2}$ & $\mathbf{9 . 7}$ & $\mathbf{1 0 . 0}$ \\
\hline
\end{tabular}




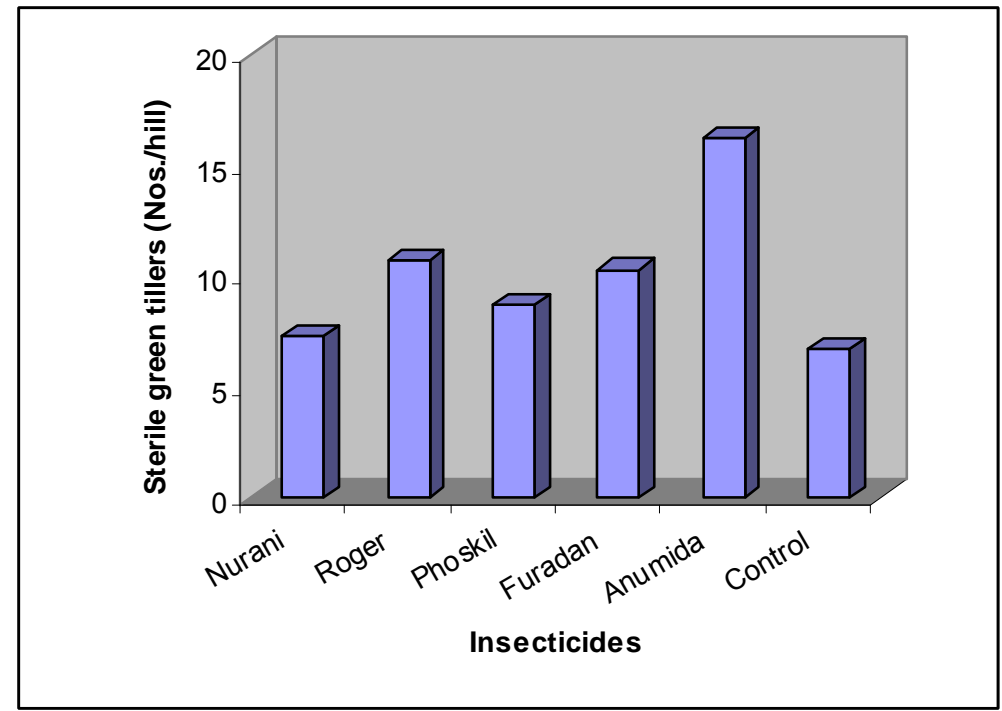

Figure 10. Sterile green tillers/hill at the time of maturity, Chitwan

\section{Fertile tiller}

The highest number of fertile tillers / hill was found with Anumida (Imidacloprid 17.8\% SL) treated hills $(\mathrm{N}=3.0)$ followed by Rogar $(\mathrm{N}=2.3)$, phoskil $(\mathrm{N}=2.0)$, Noorani $(\mathrm{N}=1.7)$ and Furadan $(\mathrm{N}=1.7)$ respectively. The number of fertile tillers / hill was seriously decreased in all the treatment hence; they were seriously affected at earlier age with the heavy population of Whitefly nymphs. However, the hills treated with insecticide successes to produce few ears. The control hills totally failed to produce the ears (Figure 11, Table 7).

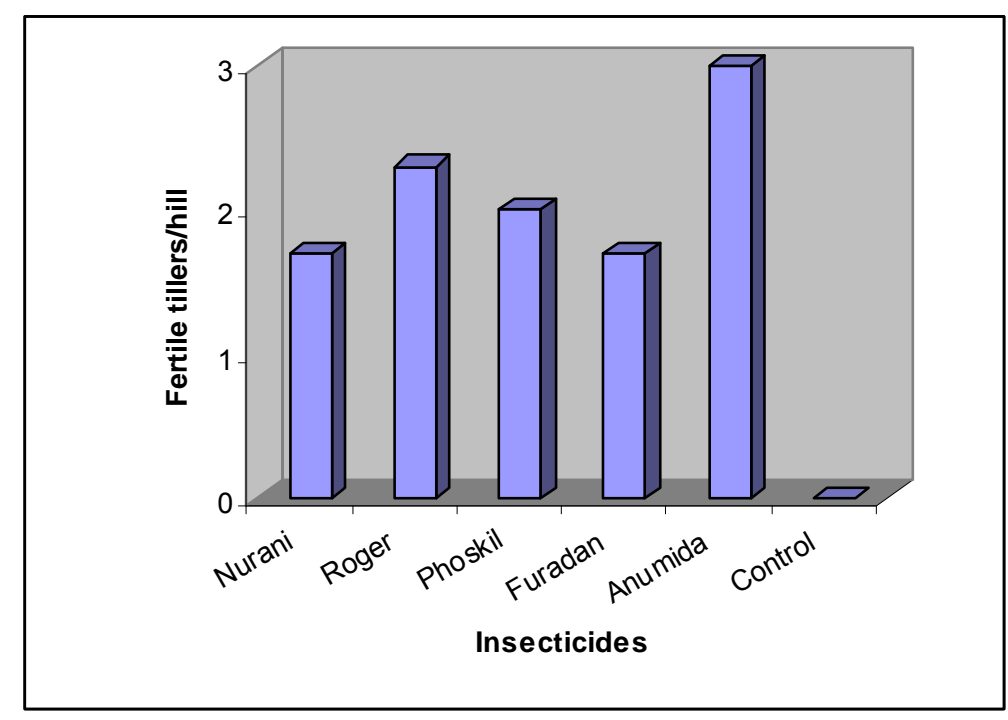

Figure 11. Fertile tillers/hill at the time of maturity, Chitwan 
Table 7. Difference on ear emergence on main season rice, Bharatpur, Chitwan

\begin{tabular}{llcccc}
\hline \multirow{2}{*}{ SN } & \multirow{2}{*}{ Treatment } & \multicolumn{5}{c}{ Ear number (Nos/hill) } \\
\cline { 3 - 6 } & & R1 & R2 & R3 & T mean \\
\hline 1 & Noorani & 1 & 2 & 2 & 1.7 \\
2 & Roger & 2 & 3 & 2 & 2.3 \\
3 & Phoskil & 2 & 2 & 2 & 2.0 \\
4 & Furadan & 2 & 1 & 2 & 1.7 \\
5 & Anumida & 3 & 3 & 3 & 3 \\
6 & Control & 0 & 0 & 0 & 00 \\
& R mean & $\mathbf{1 . 7}$ & $\mathbf{1 . 8}$ & $\mathbf{1 . 8}$ & $\mathbf{1 . 8}$ \\
\hline
\end{tabular}

\section{Grain production}

Chemical treatment against whitefly significantly produced higher grain number/hills. The number of grains/hills was the highest with Anumida (Imidacloprid 17.8\% SL) treated pots $(\mathrm{N}=26.3)$ followed by Rogar $(\mathrm{N}=25.0)$, Phoskil $(\mathrm{N}=11.3)$, Noorani $(\mathrm{N}=12.7)$ and Furadan $(\mathrm{N}=11.3)$ respectively (Figure 12, Table 8 ). Control hills failed to produce ears and grains.

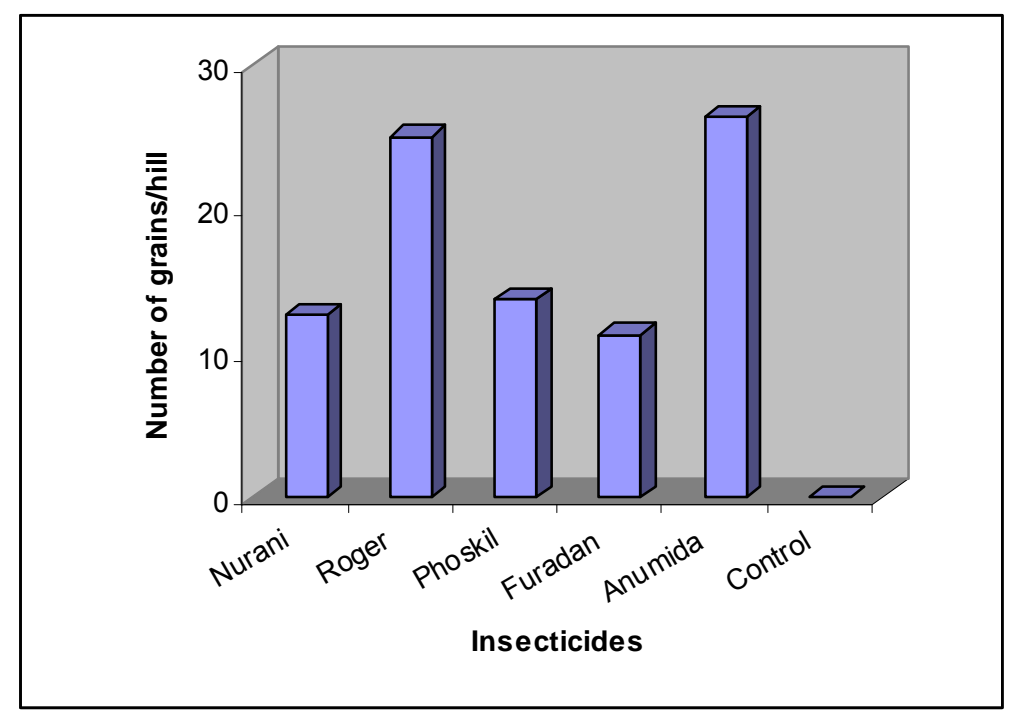

Figure 12. Filled grains/hill at the time of maturity, Chitwan 
Table 8. Filled grains per hill on main season rice, Bharatpur, Chitwan

\begin{tabular}{llcccc}
\hline \multirow{2}{*}{ SN } & \multirow{2}{*}{ Treatment } & \multicolumn{4}{c}{ Grain number (Nos/hill) } \\
\cline { 3 - 6 } & & R1 & R2 & R3 & T mean \\
\hline 1 & Noorani & 15 & 11 & 12 & 12.7 \\
2 & Roger & 27 & 23 & 25 & 25.0 \\
3 & Phoskil & 12 & 14 & 15 & 13.7 \\
4 & Furadan & 10 & 12 & 12 & 11.3 \\
5 & Anumida & 26 & 28 & 25 & 26.3 \\
6 & Control & 0 & 0 & 0 & 00 \\
& R mean & $\mathbf{1 5 . 6}$ & $\mathbf{1 4 . 7}$ & $\mathbf{1 4 . 8}$ & $\mathbf{1 4 . 8}$ \\
\hline
\end{tabular}

\section{Conclusion and recommendation}

An integrated pest management system against rice Whitefly is suggested through farmer's field school. Promotion of bio-control, selection of resistant varieties and development of appropriate cultural practices against it could be the alternative methods to be addressed for the long. However, for the immediate remedy the decision based chemical control based on the ETL is recommended. For which, Anumida (Imidacloprid 17.8\% SL) @ 1ml / 4 litre of water is suggested. It is also claimed to be not extremely hazardus and is degradable in nature. Moreover, Rogar@1.5 ml / litre of water, Phoskil (monocrotophos) @2ml / litre of water, Noorani (Chloropyrifos 50\% + Cypermethrine 5\% EC) @ 2ml/litre of water and Furadan@1 kg a .i / ha also can serve the purpose.

\section{References}

Acmsabiti. 2004. Pest control. Online communication, http:/www.acmsabati.com.my/asp/ productapplaud.htm.

Bista, DB. 2002. Food security in the Nepalese context. Paper presented in the training program entitled "Agricultural plan formulation and management training", conducted by CATC for the second class GT officers.

CBS (Central Bureau of Statistics). 1999. Statistical yearbook of Nepal. 450p.

DADO (District Agriculture Development Office, Chitwan) staff discussion. 2060.

DADO (District Agriculture Development Office, Chitwan). 1996. Annual report 1996. 59 p.

Gorkhapatra daily. Sep. 11, 1996.

Himalayan times. Sep.30, 1996.

Nutrimac, S. 2004. Online communication, http:/www.greenmethods.com

PAU (Punjab Agriculture University). 2004. Online communication, http:/www.pau.edu/ website/ message/-htm. 
PCIP (Pest Control India Pvt. Ltd.). 2004. Whitefly. Online communication, http:/www.pcilindia. com/know/white-fly.html.

Pokhrel, S, PN Sharma and FP Neupane. 1998-1999. Incidence and control of the rice plant hoppers in Chitawan Nepal, Journal of the Institute of Agriculture and Animal Science 19-20: 55-64.

Pokhrel, S. 2002. Incidence and management of the rice plant hoppers and the impact of FFS in Chitwan Nepal, A case study cum review paper summated to CATC for the partial fulfillment of "Agricultural plan formulation and management training" conducted by CATC for the second GT officers. 53p.

Pokhrel, S. 2003. Whitefly and Mealybug threat on rice production in Chitwan valley, Nepal. A research article on incidence, natural control and yield loss assessment cum seminar paper, presented at Institute of Agriculture and Animal Sciences for the partial fulfillment of PhD in Agriculture.

TWFP (Tropical Whitefly IPM Project). 2005. A new Whitefly species emerges as a pest of cereals. Online communication http:/www.tropical whiteflyipmproject.cgiar.org. 